\title{
Clinicopathological features and treatment outcomes of the rare, salivary duct carcinoma of parotid gland
}

\author{
Khalid Hussain AL-Qahtani ${ }^{1}$, Mutahir A. Tunio ${ }^{3^{*}}$, Yasser Bayoumi², Venkada Manickam Gurusamy ${ }^{3}$, \\ Fahad Ahmed A. Bahamdain ${ }^{4}$ and Hanadi Fatani ${ }^{5}$
}

\begin{abstract}
Background: Salivary ductal carcinoma (SDC) of parotid gland is a rare and aggressive entity; accounting for 1-3\% of all malignant salivary gland tumors, $0.2 \%$ of epithelial salivary gland neoplasms, $0.5 \%$ of salivary gland carcinomas, and $1.1 \%$ of parotid gland carcinomas. Here in we aimed to evaluate the clinico-pathological features and treatment outcomes of parotid gland SDC in Saudi population.

Methods: Among 38 patients with parotid malignancies, who were treated in two major tertiary care referral cancer centers between December 2007 and December 2014, seven cases (18.4\%) were found to have SDC, which were investigated for clinicopathological features, locoregional recurrences (LRRs), distant metastasis (DM) and survival rates.

Results: Mean age of cohort was 62.3 years (range: 41-83) and female predominant (71.4\%). All patients underwent total parotidectomy and ipsilateral neck dissection. Mean tumor size was $3.4 \mathrm{~cm}$ (range: 2.1-5.3); perineural invasion (85.8 \%); lymph node involvement (42.9\%); and HER-2 neu overexpression (28.6\%). Postoperative radiation therapy (PORT) was given to six patients (dose: 50-66 Gy). Median follow-up was 20.2 months (range: 11-48). LRRs were seen in five (71.4 \%) patients (base of skull, 3 patients; cervical nodes, one patient; parotid bed, one patient). LRRs were salvaged with resection (two patients) and re-irradiation (one patient with base of skull). DM in lungs was seen in three patients (42.8\%); one treated with carboplatin/paclitaxel based chemotherapy. The 4-year disease free and overall survival rates were $16.7 \%$ and $40 \%$ respectively.

Conclusion: SDC of parotid gland is a rare and aggressive entity, and most of LRRs were seen in the base of skull, which warrants inclusion of base of skull in clinical target volume in PORT planning. Role of anti HER-2 targeted therapy in SDC with HER-2 neu overexpression needs further investigations.
\end{abstract}

Keywords: Salivary ductal carcinoma, Parotid gland, Saudi population

\section{Background}

Salivary ductal carcinoma (SDC) of parotid gland is a rare and aggressive entity; accounting for $1-3 \%$ of all malignant salivary gland tumors, $0.2 \%$ of epithelial salivary gland neoplasms, $0.5 \%$ of salivary gland carcinomas, and $1.1 \%$ of parotid gland carcinomas [1,2]. SDC of parotid gland has been classified as high grade tumors along with high-grade mucoepidermoid carcinoma and carcinoma ex pleomorphic adenoma in the updated World Health Organisation (WHO) classification of

\footnotetext{
* Correspondence: drmutahirtonio@hotmail.com

${ }^{3}$ Radiation Oncology, King Fahad Medical City, Riyadh 59046, Saudi Arabia

Full list of author information is available at the end of the article
}

salivary gland tumors [3]. The histopathological features of SDC of parotid gland are similar to those of breast ductal carcinoma requiring a differential diagnosis with possible metastasis through immunohistochemistry (IHC) analysis among patients with a previous history of breast carcinoma [4].

The standard treatment for SDC of parotid gland is total parotidectomy, ipsilateral neck dissection followed by postoperative radiation therapy with or without concurrent chemotherapy; however, SDC of parotid gland has grave dismal prognosis [5]. 
Here in, we describe and discuss the clinicopathological characteristics and treatment outcomes SDC of parotid gland in our population.

\section{Methods}

After formal approval from the institutional review committee, medical records of 38 patients with confirmed parotid gland malignancies, who were treated in two cancer centers of Riyadh, Saudi Arabia during the period of December 2007 and December 2014, were reviewed using digital database system. Patients with SDC of parotid gland were retrieved in following manner;

\section{Demographic, clinicopathological and radiological variables}

Demographic and clinical data including age at the diagnosis, gender, and signs and symptoms at the time of presentation were reviewed. A detailed second review of all histopathological specimens was performed by experienced histopathologist. Different histopathological parameters, including the tumor size, lymphovascular space invasion (LVSI), perineural invasion (PNI), margin status, lymph node involvement and tumor, lymph node and metastasis (TNM) staging were recorded. Data from different imaging modalities, including computed tomography (CT) scan of neck and chest, magnetic resonance imaging (MRI) and flourodeoxyglucose positron emission tomography (FDGPET) was collected. Data regarding different treatment modalities, including the type of parotidectomy and neck dissection, postoperative radiation therapy (PORT), and its doses were also recorded.

\section{Statistical analysis}

The primary endpoint was locoregional control (LRC). Secondary points were the distant metastasis control (DMC), disease free survival (DFS) and overall survival (OS) rates. Locoregional recurrence (LRR) was defined as, the duration between the parotidectomy and the date of clinically or radiologically detectable disease in the parotid bed or in cervical lymph nodes on imaging. Distant metastasis (DM) was defined as, the duration between the parotidectomy and the date of documented disease outside the neck on imaging. Similarly, DFS was defined as, the duration between the parotidectomy and the date of documented disease reappearance/relapse, death from cancer and/or last follow-up (censored). The OS was defined as, the duration between the surgery and the date of patient death or last follow-up (censored). Probabilities of LRC, DMC, DFS and OS rates were shown with the Kaplan-Meier method, and the comparisons for various survival curves were performed using log rank. All statistical analyses were performed using the computer program SPSS version 16.0. Relevant literature was searched through PubMed/MEDLINE, CANCERLIT, EMBASE, Cochrane Library database,
Web of Science, Academic Search Premier, and CINAHL using the terms "(salivary duct carcinoma, ductal carcinoma parotid, Stensen duct carcinoma of parotid. These terms were then combined for search for prospective, retrospective, randomized, controlled, review articles.

\section{Results}

Among thirty eight patients with parotid malignant tumors who were treated in our centers between December 2007 and December 2014, seven cases (18.4 \%) were found to have SDC. Mean age of cohort was 62.3 years (range: 41-83), with female preponderance (71.4\%). The common presentation at the diagnosis was the parotid swelling. In two patients ( $28.6 \%)$, facial nerve palsy was seen at the time of diagnosis. Patient characteristics are shown in Table 1.

All patients underwent total parotidectomy and modified ipsilateral neck dissection. Mean tumor size was $3.4 \mathrm{~cm}$ (range: 2.1-5.3). Predominant histopathological pattern was the neoplasm was comprised of cribriform growth pattern with central comedo necrosis, and tumor cells were polygonal with distinct cell borders, with pleomorphic nuclei and increased mitotic activity (Fig. 1a and b). PNI was observed in 6/7 cases (85.8 \%), while LVSI was seen in 3/7 patients (42.9\%). Lymph node involvement was observed in 3/7 cases (42.9\%). HER-2 neu was overexpressed in $2 / 7$ cases $(28.6 \%)$.

PORT via IMRT was given to $6 / 7$ cases $(85.8 \%)$. Indications were positive margins $(66.7 \%)$, and lymph node metastasis (50\%). Median delay between surgery and PORT was 6 weeks (range: 5.5-8). The treatment fields encompassed the tumor bed and upper neck (4 patients), and tumor bed and entire neck (2 patients). Cranial border of PORT fields were kept at base of skull in 2 patients. Mean dose for PORT was $61.3 \mathrm{~Gy}$ (range: 50-66 Gy), given as daily $2 \mathrm{~Gy} /$ fraction, 5 days/week over 6-6.5 weeks (30-33 fractions).

Median follow-up was 20.2 months (range: 11-48). LRRs were seen in five $(71.4 \%)$ patients. One LRR was in patient without PORT, Two LRRs were marginal near PORT fields (mastoid air cells/base of skull; 3 patients) Fig. 2a and b; two LRRs were seen in-field PORT (cervical nodes; one patient, parotid bed; one patient) Fig. 3. LRRs were salvaged with resection (two patients) and re-irradiation via IMRT (one patient with base of skull recurrence) and systemic chemotherapy (one patient). DM in lungs was seen in three patients (42.8\%); one treated with carboplatin/paclitaxel based chemotherapy. At the time of analysis, four patients $(57.2 \%)$ were alive and were disease free. The median time to survival was 15.8 months. The 4-year LRC, DMC, DFS and OS rates were $20.8 \%, 40 \%, 16.7 \%$ and $40 \%$ respectively Fig. $4 \mathrm{a}$ and $\mathrm{b}$. 
Table 1 Patient characteristics

\begin{tabular}{|c|c|c|c|c|c|c|c|c|}
\hline Patient & $\begin{array}{l}\text { Age } \\
\text { /gender }\end{array}$ & Symptoms & Treatment & Pathology & Recurrence & Metastasis & Died & $\begin{array}{l}\text { Follow-up } \\
\text { period }\end{array}$ \\
\hline 1. & $52 / F$ & $\begin{array}{l}\text { Left parotid } \\
\text { swelling, facial } \\
\text { nerve palsy }\end{array}$ & $\begin{array}{l}\text { Total parotidectomy and } \\
\text { ipsilateral MND }\end{array}$ & $\begin{array}{l}\text { Tumor size: } 2 \times 3 \mathrm{~cm} \text {; LVSI -: PNI-; } \\
\text { O/20 LN; HER-2 neu +++; Margins-; }\end{array}$ & $\begin{array}{l}\text { Base of skull with ICE (VI,VIIIIIX,X,XI CN } \\
\text { palsy) Treated with Palliative RT } 25 \\
/ 10\end{array}$ & Bilateral Lungs & Yes & 14 months \\
\hline 2. & $41 / \mathrm{M}$ & $\begin{array}{l}\text { Right parotid } \\
\text { swelling }\end{array}$ & $\begin{array}{l}\text { Total parotidectomy + } \\
\text { ipsilateral MND } \rightarrow \text { RT } 60 \text { Gy/ } \\
30 \text { fractions }\end{array}$ & $\begin{array}{l}\text { Tumor size: } 3 \times 3 \mathrm{~cm} \text {; LVSI-, PNI+; 0/ } \\
\text { 30LN; HER-2 neu +++; margins- }\end{array}$ & No & No & No & 11 months \\
\hline 3. & 83/M & $\begin{array}{l}\text { Right parotid } \\
\text { swelling }\end{array}$ & $\begin{array}{l}\text { Total Parotidectomy + } \\
\text { ipsilateral MND } \rightarrow \text { RT } 50 \text { Gy/ } \\
25 \text { fractions }\end{array}$ & $\begin{array}{l}\text { Tumor size: } 2 \times 2 \mathrm{~cm} \text {; LVSI-;PNI+; 0/ } \\
10 \text { LN; HER-2 neu -; margins+, }\end{array}$ & No & Bilateral Lungs & Yes & 13 months \\
\hline 4. & $43 / F$ & $\begin{array}{l}\text { Right parotid } \\
\text { swelling }\end{array}$ & $\begin{array}{l}\text { Total parotidectomy + } \\
\text { ipsilateral MND } \rightarrow 66 \mathrm{GY} / 33 \\
\text { fractions }\end{array}$ & $\begin{array}{l}\text { Tumor size: } 4 \times 3 \mathrm{~cm} ; \text { LVSI+; PNI+; } \\
\text { HER-2 neu -; skin +; } 2 / 30 L N+\text {; mar- } \\
\text { gins+ }\end{array}$ & $\begin{array}{l}\text { Mastoid air cells and base of skull } \\
\text { Treated with Reirradiation } 60 \mathrm{~Gy} / 30 \\
\text { fractions }\end{array}$ & No & No & 27 months \\
\hline 5. & $65 / F$ & $\begin{array}{l}\text { Right parotid } \\
\text { swelling }\end{array}$ & $\begin{array}{l}\text { Total parotidectomy + } \\
\text { ipsilateral MND } \rightarrow \text { RT } 66 \text { Gy/ } \\
33 \text { fractions }\end{array}$ & $\begin{array}{l}\text { Tumor size: } 4 \times 4 \mathrm{~cm} \text {; LVSI-; PNI+; } \\
\text { HER-2 neu -; } 5 / 14 \mathrm{LN+;} \text { margins+, }\end{array}$ & $\begin{array}{l}\text { Ipsilateral Neck nodes level III, IV } \\
\text { Treated with salvage LND }\end{array}$ & No & No & 12 months \\
\hline 6. & $81 / F$ & $\begin{array}{l}\text { Right parotid } \\
\text { swelling, facial } \\
\text { nerve palsy }\end{array}$ & $\begin{array}{l}\text { Total parotidectomy + } \\
\text { ipsilateral MND } \rightarrow \text { RT } 66 \text { Gy/ } \\
33 \text { fractions }\end{array}$ & $\begin{array}{l}\text { Tumor size: } 5 \times 5 \mathrm{~cm} \text {; LVSI+; PNI+; } \\
\text { HER-2 neu -; } 3 / 21 \mathrm{LN}+\text {; margins + }\end{array}$ & $\begin{array}{l}\text { Mastoid air cells and base of skull } \\
\text { treated with chemotherapy }\end{array}$ & $\begin{array}{l}\text { Bilateral Lung treated with } \\
\text { Carboplatin/Paclitaxel } \\
\text { chemotherapy }\end{array}$ & Yes & 16 months \\
\hline 7. & $71 / F$ & $\begin{array}{l}\text { Left parotid } \\
\text { swelling }\end{array}$ & $\begin{array}{l}\text { Total parotidectomy + } \\
\text { ipsilateral MND } \rightarrow \text { RT } 60 \text { Gy/ } \\
30 \text { fractions }\end{array}$ & $\begin{array}{l}\text { Tumor size: } 3 \times 3 \mathrm{~cm} \text {; LVSI +; 0/ } \\
\text { 22LN; PNI+; HER-2 neu -; margins- }\end{array}$ & $\begin{array}{l}\text { Tumor bed Treated with resection } \\
\text { Pathology } 1.2 \mathrm{~cm} \mathrm{SDC}\end{array}$ & No & No & 48 months \\
\hline
\end{tabular}

$F$ female, $M$ male, MLND modified neck dissection, $R T$ radiation therapy, LVSI lymphovascular space invasion, PNI perineural invasion, LN lymph nodes, ICE intracranial extension, SDC salivary duct carcinoma 

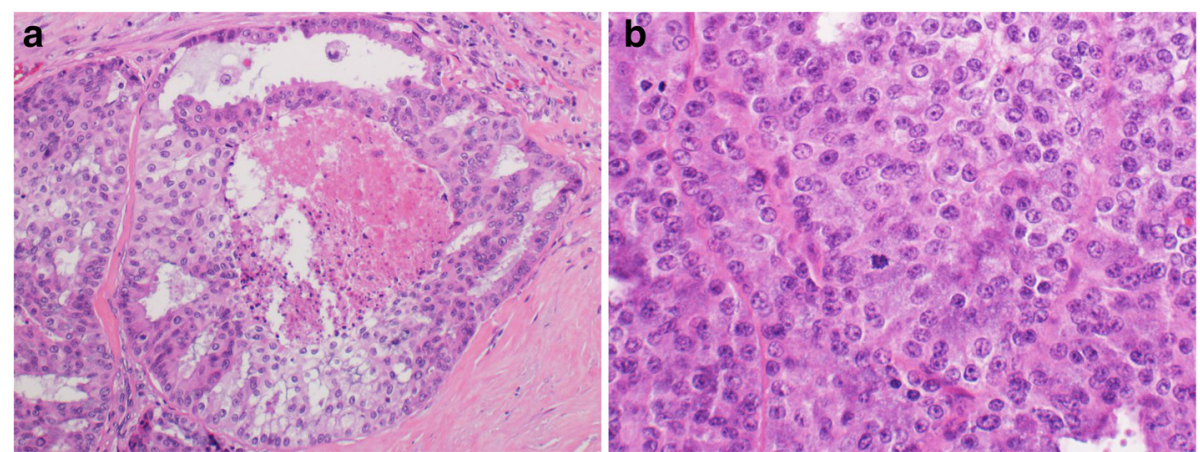

Fig. 1 a Neoplasm is comprised of cribriform growth pattern with central comedo necrosis ( $H$ \& E stain, $200 \mathrm{X}$ magnifications); b neoplastic cells have polygonal morphology, distinct cell borders, moderately pleomorphic nuclei and increased mitotic activity (H \& E stain, 400 X magnifications)

\section{Discussion}

SDC is an extremely rare and aggressive malignancy of the salivary glands. Owing to its rare nature, clinical data is scanty and only a few clinical studies comprise more than 50 SDC patients $[4,6-8]$. To date, largest SDC study has been reported from the Surveillance, Epidemiology, and End Results (SEER) database, based on 228 patients [9]. This review reported that poor prognostic factors for OS and DFS in SDC patients were age 50 years or above, tumor size, and lymph node involvement. However, this study was criticized for the diagnostic bias. Similar other studies have been mentioned in Table 2 [3, 4, 6-8, 10-21]. However, none of these studies has evaluated clinico-pathological features, DFS and OS in SDC of the parotid gland separately, which was the aim of present study. Reason for lower incidence of facial nerve involvement at the time of diagnosis $(28.6 \%)$ in our series as compared to reported data can be explained by the fact that the preoperative facial nerve function was not available for many patients, so facial nerve sacrifice at the time of parotidectomy was used as a surrogate for preoperative facial nerve palsy.
Our series was predominantly female gender (71.4\%), which is in agreement with one study by Hosal AS et al. [15], while other studies have shown a male preponderance ranging from $53.8 \%$ to $94.7 \%$ [11, 19]. In present study, relatively high incidence of pathological positive cervical lymph nodes (42.9\%) was found in agreement with reported literature, and it warrants routine use of prophylactic ipsilateral neck dissection in SDC of the parotid gland. Similarly, the percentage of pathologically positive PNI (85.8 \%) was significantly high in our series, which supports the notion that CTV should include the cranial nerves involved and the corresponding parts of the base of skull in cases of pathologically positive PNI [22]. Interestingly, in our series, no contralateral neck recurrence was seen, therefore the role of prophylactic contralateral neck irradiation needs further investigation.

HER-2 neu overexpression (28.6\%) was much lower than those reported in literature [3, 6, 13]. Recent data has shown that HER-2 neu overexpression and targeted therapy with Trastuzumab therapy is associated with improved DFS and OS rates [23]. Given the limited published data on use of adjuvant or maintenance Trastuzumab in SDC of parotid
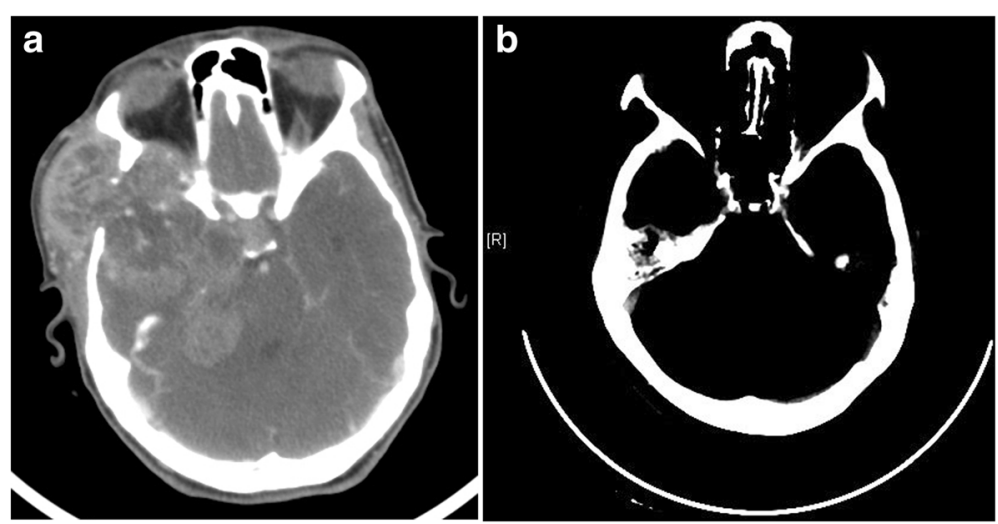

Fig. 2 a CT head axial image (patient \# 1) showing a destructive recurrent mass in the right sphenoid wing, extending into middle and posterior cranial fossae with destruction of a large portion of the skull base; $\mathbf{b} C T$ head (patient \# 4) demonstrating heterogeneous soft tissue recurrent mass involving the right mastoid air cells, mastoid bone and occipital bone associated with bone destruction 


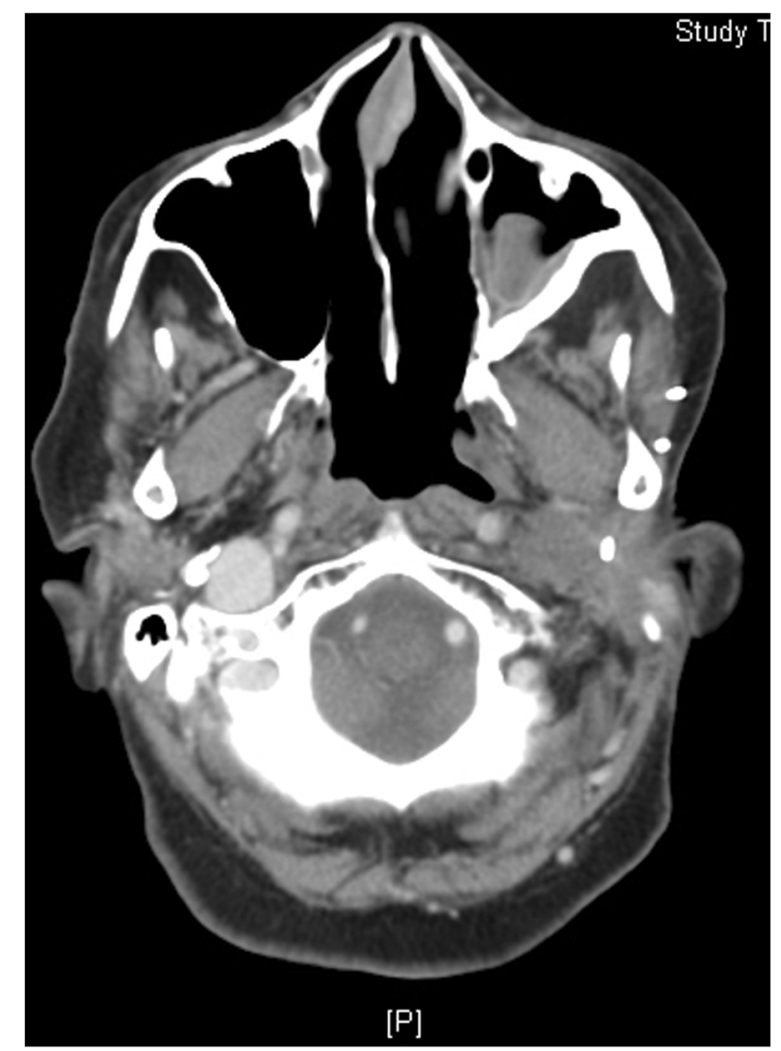

Fig. 3 Magnetic resonance imaging (MRI) face showing recurrent mass in parotid bed gland, it might also be useful to develop future Trastuzumab trials in SDC from HER-2 neu positive breast cancer [24]. As SDC of parotid gland has morphologic and molecular similarity to breast cancer, it is recommended that apart from regular histopathological examination, additional immunohistochemical staining including HER-2 neu, Ki-67, p16, p53, estrogen receptors (ER), progesterone receptors $(\mathrm{PR})$, epithelial membrane antigen (EMA), and carcinoembryonic antigen (CEA) should be performed, as proposed by many studies $[25,26]$.

In contrast to other studies, about $60 \%$ of LRRs were seen in base of skull (PORT was given in 2 patients) in our series, which further supports the hypothesis of inclusion of base of skull in CTV during PORT for these patients as in patients with parotid gland adenoid cystic carcinoma [27]. One LRR in base of skull was salvaged by re-irradiation using IMRT with acceptable toxicity. However, data from re-irradiation in adenoid cystic carcinoma has shown that most of LRRs following reirradiation occur within the re-irradiated high-dose region, therefore more data regarding dose escalation and delayed toxicity is required [28].

Our study has few limitations. A relatively small number of patients were studied, due to the rarity of SDC in our population. Further, PORT fields, techniques and doses varied somewhat in our study.

\section{Conclusions}

SDC of parotid gland is rare and aggressive entity. Despite extensive treatment by parotidectomy, neck dissection and PORT; a large proportion of patients developed all-sites recurrences. Base of skull should be included
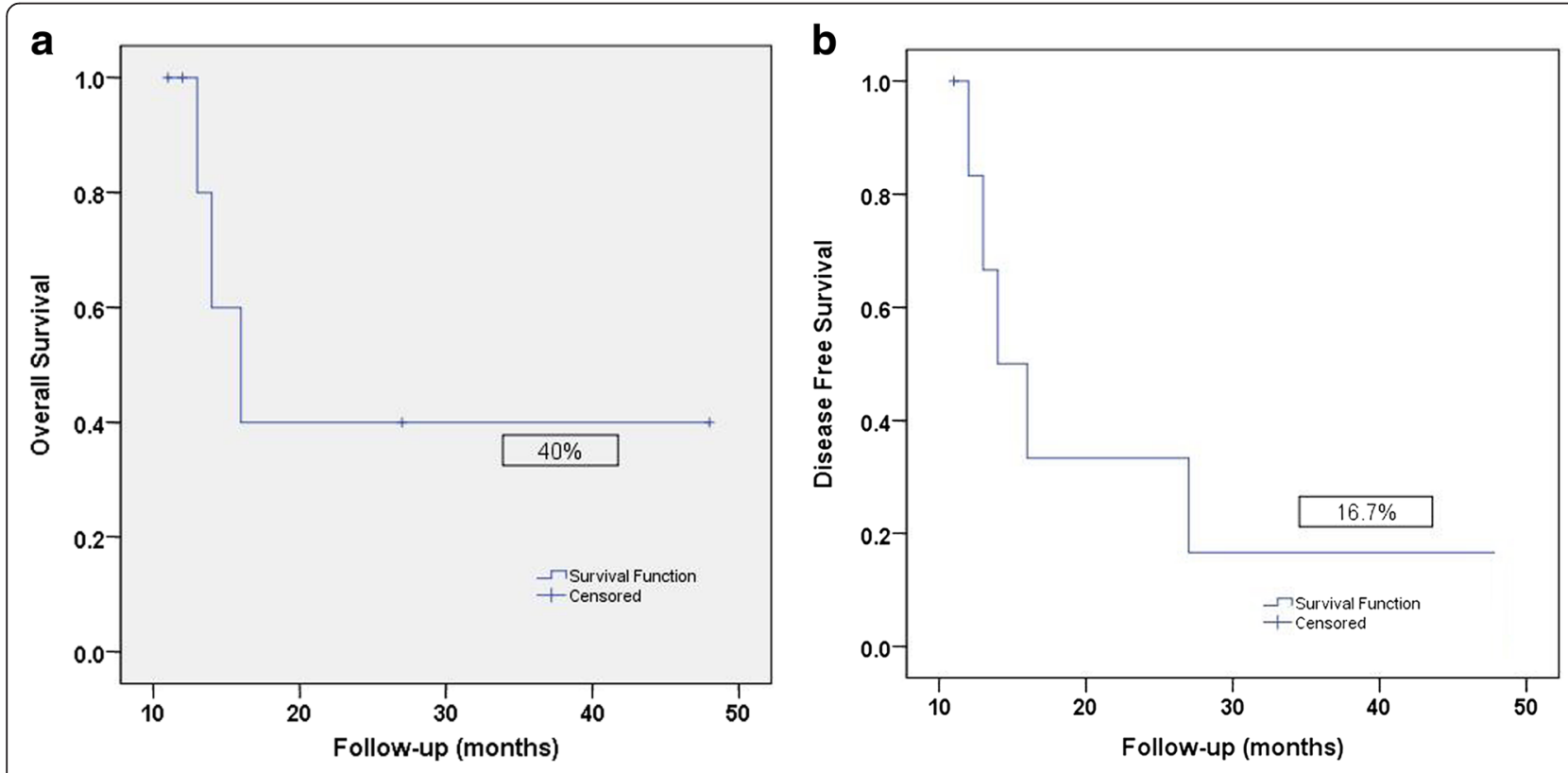

Fig. 4 a 4- year OS and $\mathbf{b}$ 4-year DFS rates for SDC in our cohort 
Table 2 Previously published studies on salivary duct carcinoma of Parotid gland

\begin{tabular}{|c|c|c|c|c|c|c|c|c|c|c|}
\hline Study & Patients & Parotid SDC & $\mathrm{LN}+$ & $\mathrm{PNI}$ & HER-2 neu expression & PORT & Follow-up Mean & LRR & $\mathrm{DM}$ & OS \\
\hline Huang $X$, et al. [3] & 117 M (63.6 \%) & $7(63.6 \%)$ & $6(54.5 \%)$ & $5(45.5 \%)$ & 9 (81.8) & 8 (72.7 \%) Dose: 50-60 & 30 months & $2(18.2 \%)$ & $2(18.2 \%)$ & 2 2-year $75 \%$ \\
\hline Jaehne $M$, et al. [4] & 5030 M (60\%) & 39 (78 \%) & $28(56 \%)$ & - & - & $36(72 \%)$ & 24 months & $24(48 \%)$ & $24(48 \%)$ & $66 \%$ \\
\hline Gilbert MR, et al. [6] & 7553 M (71 \%) & $62(83 \%)$ & $54(72 \%)$ & $52(69 \%)$ & $23(31 \%)$ & 31 (41\%) & 55 months & 0 & 0 & 3 year $50 \%$ \\
\hline Johnston ML, et al. [7] & $54-$ & 49 (90.7\%) & $38(67 \%)$ & - & - & 48 (89 \%) Dose: 60 Gy & 68.4 months & $16(29.6 \%)$ & $28(51.8 \%)$ & $43 \%$ \\
\hline Roh JL, et al [8] & 56 & $34(62 \%)$ & $38(67 \%)$ & - & - & $21(37.5)$ & 60 months & & $71 \%$ & $44 \%$ \\
\hline Kim TH, et al. [10] & 1512 M (80 \%) & $12(80 \%)$ & $9(60 \%)$ & $8(53.3 \%)$ & - & 15 (100\%) & 38 months & $2(13.3 \%)$ & $7(47 \%)$ & $93 \%$ \\
\hline Shi S, et al. [11] & 3836 M (94.7 \%) & $38(100)$ & - & - & - & - & 48 months & - & - & $45 \%$ \\
\hline Kim JY, et al. [12] & 3530 M (85.7 \%) & $22(62.9 \%)$ & $26(74.3 \%)$ & $12(34.3 \%)$ & - & 31 (88.6 \%) & 36 months & $9(25.7 \%)$ & $6(17.2 \%)$ & $55.1 \%$ \\
\hline Brandwein-Gensler M, et al. [13] & 19 & - & - & - & $10(52.6 \%)$ & - & 30 months & - & - & $68.4 \%$ \\
\hline Luna MA, et al. [14] & 3019 M (63.3 \%) & $24(80 \%)$ & $16(66.7 \%)$ & - & - & - & 24 months & $16(66.7 \%)$ & $16(66.7 \%)$ & $30 \%$ \\
\hline Colmenero Ruiz C, et al. [15] & 97 M (77.8 \%) & $8(88.9 \%)$ & $3(37.5 \%)$ & - & - & 7 (87.5 \%) & 30 months & $5(55.6 \%)$ & $3(33.5 \%)$ & $33 \%$ \\
\hline Delgado R, et al. [16] & 1512 M (80 \%) & $13(86.7 \%)$ & $2(13.3 \%)$ & - & - & $9(60 \%)$ & - & $5(33 \%)$ & $6(40 \%)$ & $47 \%$ \\
\hline Guzzo M, et al. [17] & 2614 M (53.8 \%) & $21(80.7 \%)$ & $15(57.7 \%)$ & - & - & $17(65.4 \%)$ & 60 months & $11(42.3 \%)$ & $12(46.2 \%)$ & $46 \%$ \\
\hline Hosal AS, et al. [18] & $157 \mathrm{M}(46.7 \%)$ & $12(80 \%)$ & $11(73.3 \%)$ & - & - & $14(93.3 \%)$ & 48 months & $8(53.3 \%)$ & $7(46.7 \%)$ & $43 \%$ \\
\hline Ko YH, et al. [19] & 2716 M (56.3 \%) & $21(77.8 \%)$ & $10(37.1 \%)$ & - & - & 19 (70.4 \%) & 30 months & 9 (33.3 \%) & 15 (55.6 \%) & $44 \%$ \\
\hline Afzelius LE, et al. [20] & 127 M (58.3 \%) & $12(100 \%)$ & $5(41.7 \%)$ & - & - & $12(100 \%)$ & 60 months & $3(25 \%)$ & $6(50 \%)$ & $42 \%$ \\
\hline Lewis JE, et al. [21] & 2617 M (65.4 \%) & $23(88.5 \%)$ & $19(73.1 \%)$ & - & - & $13(50 \%)$ & 60 months & $15(57.7 \%)$ & $11(43 \%)$ & $43 \%$ \\
\hline Our study & 72 M (28.6 \%) & 7 (100 \%) & $3(42.9 \%)$ & $6(85.8 \%)$ & $2(28.6 \%)$ & $6(85.8 \%)$ & 20.2 months & $5(71.4 \%)$ & $3(42.8 \%)$ & $40 \%$ \\
\hline
\end{tabular}


routinely in CTV during PORT, and HER-2 neu status should also be examined routinely in all these patients. Further, large multi-institutional studies regarding the role of re-irradiation, systemic chemotherapy, trastuzumab are warranted to suggest optimal treatment approaches for SDC of parotid gland.

\section{Competing interests}

The authors declare that they have no competing interests.

\section{Authors' contributions}

$\mathrm{KQ}, \mathrm{YB}$ and MT participated in the design of the study and performed the statistical analysis. VMG, YB and FAB collected the data and drafted the manuscript. HF carried out the histopathology data collection and edited the manuscript. All authors read and approved the final manuscript.

\section{Acknowledgement}

We are thankful to Laura Stanciu Gabriella for her efforts in the revision of manuscript and drafting.

\section{Author details}

${ }^{1}$ Department of Otolaryngology-Head \& Neck Surgery, College of Medicine, King Saud University, Riyadh, Saudi Arabia. ${ }^{2}$ Radiation Oncology, NCl, Cairo University, Cairo, Egypt. ${ }^{3}$ Radiation Oncology, King Fahad Medical City, Riyadh 59046, Saudi Arabia. ${ }^{4}$ Faculty of Medicine, King AbdulAziz University, Riyadh 59046, Saudi Arabia. ${ }^{5}$ Histopathology, Comprehensive Cancer Center, King Fahad Medical City, Riyadh 59046, Saudi Arabia.

\section{Received: 5 January 2016 Accepted: 11 May 2016}

Published online: 16 May 2016

\section{References}

1. Pont E, Pla A, Cruz Mojarrieta J, Ferrandis E, Brotons S, Vendrell JB. Salivary duct carcinoma: diagnostic clues, histology and treatment. Acta Otorrinolaringol Esp. 2013;64:150-3

2. Xie S, Yang H, Bredell M, Shen S, Yang H, Jin L, Zhang S. Salivary duct carcinoma of the parotid gland: A case report and review of the literature. Oncol Lett. 2015:9:371-4.

3. Huang X, Hao J, Chen S, Deng R. Salivary duct carcinoma: A clinopathologica report of 11 cases. Oncol Lett. 2015;10:337-41.

4. Jaehne M, Roeser $K$, Jaekel T, Schepers JD, Albert N, Loning T. Clinical and immunohistologic typing of salivary duct carcinoma: a report of 50 cases. Cancer. 2005:103:2526-33.

5. Nabili V, Tan JW, Bhuta S, Sercarz JA, Head CS. Salivary duct carcinoma: a clinical and histologic review with implications for trastuzumab therapy. Head Neck. 2007;29:907-12.

6. Gilbert MR, Sharma A, Schmitt NC, Johnson JT, Ferris RL, Duvvuri U, Kim S. A 20-Year Review of 75 Cases of Salivary Duct Carcinoma. JAMA Otolaryngol Head Neck Surg. 2016. doi:10.1001/jamaoto.2015.3930.

7. Johnston ML, Huang SH, Waldron JN, Atenafu EG, Chan K, Cummings BJ, Gilbert RW, Goldstein D, Gullane PJ, Irish JC, Perez-Ordonez B, Weinreb I, Bayley A, Cho J, Dawson LA, Hope A, Ringash J, Witterick IJ, O'Sullivan B, Kim J. Salivary duct carcinoma: Treatment, outcomes, and patterns of failure. Head Neck. 2015. doi:10.1002/hed.24107.

8. Roh JL, Lee Jl, Choi SH, Nam SY, Kim SO, Cho KJ, Kim SB, Kim SY. Prognostic factors and oncologic outcomes of 56 salivary duct carcinoma patients in a single institution: high rate of systemic failure warrants targeted therapy. Oral Oncol. 2014:50:e64-6.

9. Jayaprakash V, Merzianu M, Warren GW, Arshad H, Hicks Jr WL, Rigual NR, Sullivan MA, Seshadri M, Marshall JR, Cohan DM, Zhao Y, Singh AK. Survival rates and prognostic factors for infiltrating salivary duct carcinoma: Analysis of 228 cases from the Surveillance, Epidemiology, and End Results database. Head Neck. 2014;36:694-70.

10. Kim TH, Kim MS, Choi SH, Suh YG, Koh YW, Kim SH, Choi EC, Keum KC. Postoperative radiotherapy in salivary ductal carcinoma: a single institution experience. Radiat Oncol J. 2014;32:125-31.

11. Shi S, Fang Q, Liu F, Zhong M, Sun C. Prognostic factors and survival rates for parotid duct carcinoma patients. J Craniomaxillofac Surg. 2014;42:1929-31.

12. Kim JY, Lee S, Cho KJ, Kim SY, Nam SY, Choi SH, Roh J L, Choi EK, Kim JH, Song SY, Shin HS, Chang SK, Ahn SD. Treatment results of post-operative radiotherapy in patients with salivary duct carcinoma of the major salivary glands. Br J Radiol. 2012;85:e947-52.

13. Brandwein-Gensler M, Hille J, Wang BY, Urken M, Gordon R, Wang LJ, Simpson JR, Simpson RH, Gnepp DR. Low-grade salivary duct carcinoma: description of 16 cases. Am J Surg Pathol. 2004;28:1040-44.

14. Luna MA, Batsakis JG, Ordonez NG, Mackay B, Tortoledo ME. Salivary gland adenocarcinomas: a clinicopathologic analysis of three distinctive types. Semin Diagn Pathol. 1987;4:117-35.

15. Colmenero Ruiz C, Patron Romero M, Martin PM. Salivary duct carcinoma: a report of nine cases. J Oral Maxillofac Surg. 1993;51:641-6.

16. Delgado R, Vuitch F, Albores-Saavedra J. Salivary duct carcinoma. Cancer. 1993;72:1503-12.

17. Guzzo M, Di Palma S, Grandi C, Molinari R. Salivary duct carcinoma: clinical characteristics and treatment strategies. Head Neck. 1997;19:126-33.

18. Hosal AS, Fan C, Barnes L, Myers EN. Salivary duct carcinoma. Otolaryngol Head Neck Surg. 2003;129:720-5.

19. Ko YH, Roh JH, Son Yl, Chung MK, Jang JY, Byun $\mathrm{H}$, Baek $\mathrm{CH}$, Jeong $\mathrm{HS}$. Expression of mitotic checkpoint proteins BUB1B and MAD2L1 in salivary duct carcinomas. J Oral Pathol Med. 2010;39:349-55.

20. Afzelius LE, Cameron WR, Svensson C. Salivary duct carcinoma-a clinicopathologic study of 12 cases. Head Neck Surg. 1987;9:151-6.

21. Lewis JE, McKinney BC, Weiland LH, Ferreiro JA, Olsen KD. Salivary duct carcinoma. Clinicopathologic and immunohistochemical review of 26 cases. Cancer. 1996:77:223-30.

22. Shinoto M, Shioyama Y, Nakamura K, Nakashima T, Kunitake N, Higaki Y, Sasaki T, Ohga S, Yoshitake T, Ohnishi K, Asai K, Hirata H, Honda H. Postoperative radiotherapy in patients with salivary duct carcinoma: clinical outcomes and prognostic factors. J Radiat Res. 2013;54:925-30.

23. Limaye SA, Posner MR, Krane JF, Fonfria M, Lorch JH, Dillon DA, Shreenivas AV, Tishler RB, Haddad RI. Trastuzumab for the treatment of salivary duct carcinoma. Oncologist. 2013;18:294-300.

24. McKeage K, Perry CM. Trastuzumab: a review of its use in the treatment of metastatic breast cancer overexpressing HER2. Drugs. 2002;62:209-43.

25. Masubuchi T, Tada Y, Maruya S, Osamura Y, Kamata SE, Miura K, Fushimi C, Takahashi H, Kawakita D, Kishimoto S, Nagao T. Clinicopathological significance of androgen receptor, HER2, Ki-67 and EGFR expressions in salivary duct carcinoma. Int J Clin Oncol. 2015;20:35-44.

26. Simpson RH, Skalova A, Di Palma S, Leivo I. Recent advances in the diagnostic pathology of salivary carcinomas. Virchows Arch. 2014;465:371-84.

27. Garden AS, Weber RS, Morrison WH, Ang KK, Peters LJ. The influence of positive margins and nerve invasion in adenoid cystic carcinoma of the head and neck treated with surgery and radiation. Int J Radiat Oncol Biol Phys. 1995;32:619-26.

28. Jensen AD, Poulakis M, Nikoghosyan AV, Chaudhri N, Uhl M, Munter MW, Herfarth KK, Debus J. Re-irradiation of adenoid cystic carcinoma: analysis and evaluation of outcome in 52 consecutive patients treated with rasterscanned carbon ion therapy. Radiother Oncol. 2015;114:182-8.

Submit your next manuscript to BioMed Central and we will help you at every step:

- We accept pre-submission inquiries

- Our selector tool helps you to find the most relevant journal

- We provide round the clock customer support

- Convenient online submission

- Thorough peer review

- Inclusion in PubMed and all major indexing services

- Maximum visibility for your research

Submit your manuscript at www.biomedcentral.com/submit 